\title{
Life cycle impact assessment of the environmental infrastructures in operation phase: Case of an industrial waste incineration plant
}

\author{
Hyeong-Woo Kim ${ }^{1}$, Kyeong-Ho Kim ${ }^{2}$, Hung-Suck Park ${ }^{3^{+}}$ \\ ${ }^{1}$ BK 21 Plus Ulsan Eco-industrial Park Project Team, University of Ulsan, Ulsan 44610, Republic of Korea \\ ${ }^{2}$ Green Manufacturing 3Rs R\&D Group, Ulsan Regional Division, KITECH, Ulsan 44413, Republic of Korea \\ ${ }^{3}$ Department of Civil and Environmental Engineering, University of Ulsan, Ulsan 44610, Republic of Korea
}

\begin{abstract}
A life cycle impact assessment was applied in an industrial waste incineration plant to evaluate the direct and indirect environmental impacts based on toxicity and non-toxicity categories. The detailed life cycle inventory of material and energy inputs and emission outputs was compiled based on the realistic data collected from a local industrial waste incineration plant, and the Korean life cycle inventory and ecoinvent database. The functional unit was the treatment of 1 tonne of industrial waste by incineration and the system boundary included the incineration plant and landfilling of ash. The result on the variation of the impact by the unit processes showed that the direct impact was decreased by 79.3 , 71.6, and $90.1 \%$ for the processes in a semi dry reactor, bag filter, and wet scrubber, respectively. Considering the final impact produced from stack, the toxicity categories comprised $91.7 \%$ of the total impact. Among the toxicity impact categories, the impact in the eco-toxicity category was most significant. A separate estimation of the impact due to direct and indirect emissions showed that the direct impact was $97.7 \%$ of the total impact. The steam recovered from the waste heat of the incineration plant resulted in a negative environmental burden
\end{abstract}

Keywords: Direct emission, Environmental impact, Incineration, Indirect emission, Industrial waste, Life cycle assessment

\section{Introduction}

In the past two decades, life cycle assessment (LCA) has been used as an important tool for assessing environmental impacts associated with a product throughout its entire life cycle, wherein the term 'product' refers to both goods and services. The LCA of a product is carried out by defining the goal and scope; by compiling an inventory of relevant inputs and outputs of the product system; evaluating the potential environmental impacts associated with those inputs and outputs; and interpreting the results of inventory analysis and impact assessment phases in relation to the objectives of the study [1].

LCA, in general, is conceptualized to change the product use practices, to preserve resources, and to protect human and ecological health with a focus on sustainable development [2]. In this sense, application of LCA to infrastructure decisions appears to be of paramount importance. Till date, many LCA studies have been conducted about infrastructure construction [3-7], transportation system [8-10], wastewater treatment system [11-14], and waste treatment systems [15-19]. In these studies,
LCA was used to evaluate the environmental performance of several infrastructures and compare various waste treatment options to determine the optimum waste management strategy (e.g., incineration, recycling and landfill) which have different performance characteristics. Usually, comparative assessment of various options is carried out early in the design of a product or process. On the other hand, if the design is finalized, or the product is in manufacture, or the process is in operation, LCA is carried out to achieve modest changes in environmental attributes at minimal cost or minimal disruption of the existing operation [20]. Anew, LCA of environmental infrastructures such as wastewater or waste treatment systems shows that the operation phase contributes to the environment impact significantly, while construction and demolition phases have a negligible environmental impact [13-14].

Environmental infrastructures are different from other infrastructure systems (Fig. 1) in a way that some pollutant 'P' enters to such infrastructures along with various other resources (e.g. chemicals and water) and energy (e.g. electricity and oil). In the output, pollutant $\mathrm{P}^{\prime}\left(\mathrm{P}^{\prime}<\mathrm{P}\right)$ is released along with wastes
This is an Open Access article distributed under the terms of the Creative Commons Attribution Non-Commercial License (http://creativecommons.org/licenses/by-nc/3.0/) which permits unrestricted non-commercial use, distribution, and reproduction in any medium, provided the original work is properly cited.
Received August 30, 2016 Accepted February 14, 2017

${ }^{\dagger}$ Corresponding author

Email: parkhs@ulsan.ac.kr

Tel: +82-52-259-1050 Fax: +82-52-221-0152

Copyright (C) 2017 Korean Society of Environmental Engineers 
(e.g. ash, sludge, leachate) and products (e.g. steam, electricity, treated water, and biogas). Thus, LCA of environmental infrastructures require a lot of data starting from their construction to demolition phases. And, by ignoring the assessment of infrastructure construction and demolition phases, more specific assessment of operation phase is warranted to recognize the poorly performing unit processes and finding the opportunity to improve the environmental performance therein. Nevertheless, estimation of both direct and indirect emissions is required for an impartial evaluation of the total environmental impact resulting from such infrastructures. While direct emissions include air emissions from stack of waste incineration plants, greenhouse gas (GHG) emission landfills, and discharge of various contaminants from wastewater treatment plants (WWTPs), indirect emissions in the upstream originate from the production of energy, chemicals and other raw materials which are used in various unit processes of the environmental infrastructures.

Even the most technologically advanced incinerators emit thousands of pollutants that contaminate air, soil and water. Several identified emissions include heavy metals such as lead, cadmium, arsenic, chromium, and mercury, halogenated hydrocarbons, acid gases, particulate matter, and volatile organic compounds such as dioxin and furans [21, 22]. Toxics are created at various stages of such thermal technologies, and not only at the end of the stack. Waste incineration systems produce a wide variety of pollutants which are detrimental to human health. Such systems are expensive and does not eliminate or adequately control the toxic emissions from chemically complex municipal solid waste (MSW) [23].

Many researchers have studied to evaluate the environmental impact for incineration plant using LCA tool, but majority of the studies focused only on the reduction of carbon dioxide to evaluate waste-to-energy system. Even though toxic matter is an

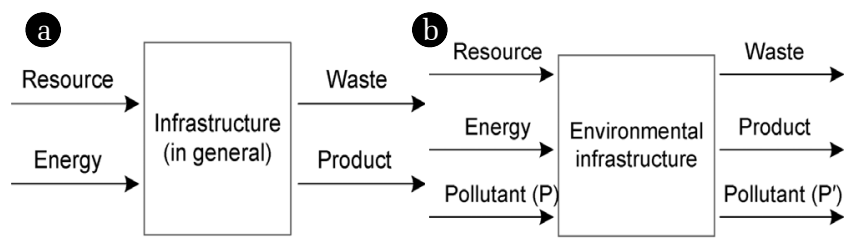

Fig. 1. Schematic diagram differentiating between a generalized infrastructure system (a), and an environmental infrastructure (b) with their inputs and outputs. important issue in the incineration field, there are still limited studies in the aspect of dealing with toxic issues. In our previous study [24], we evaluated the environmental impacts of various unit operations of an industrial waste incineration plant by using the LCA tool. The impact categories considered in the evaluation were abiotic depletion potential (ADP), acidification potential (AP), eutrophication potential (EP), global warming potential (GWP), ozone depletion potential (ODP), and photochemical oxidation potential (POCP). However, the toxicity potential was not considered. As mentioned above, because waste incineration systems produce a wide variety of pollutants which are detrimental to human health, it is necessary to evaluate the environmental impact including toxicity categories for incineration system.

In order to evaluate the life cycle environmental performance during the operation phase, this study considers an industrial waste incineration plant as a case study. The paper mainly focuses on two objectives: (i) applying LCA methodology to evaluate environmental impacts of an incineration plant in the operation phase, considering both direct and indirect emissions and toxicity categories; (ii) study the contribution of each unit process of the incineration plant and compare the performance of the plant by adding steam recovery as an auxiliary function along with waste disposal.

\section{LCA of the Unit Process of an Incineration Plant}

\subsection{Incineration Plant and Various Processes Involved}

In the incineration plant located in Ulsan industrial complex, solid wastes $(2,200 \mathrm{~kg} / \mathrm{h})$ and liquid wastes $(400 \mathrm{~kg} / \mathrm{h})$ are incinerated together with miscellaneous wastes $(1,350 \mathrm{~kg} / \mathrm{h})$. The types of wastes and their physico-chemical characteristics are shown in Table 1.

Before incineration of the waste, pretreatment is done to remove the moisture by heating the industrial wastes (miscellaneous wastes only). The incineration of the waste in the grate comprises of feeding stage, drying stage, burning stage, and post-burning stage. The temperature in the incinerator is maintained in the range of $850^{\circ} \mathrm{C}-1,050^{\circ} \mathrm{C}$. A complete incineration of organic components in the flue gases is assured in the afterburner chamber through appropriate air intake, high

Table 1. Physico-chemical Characteristics of Industrial Wastes

\begin{tabular}{|c|c|c|c|c|c|c|c|c|c|}
\hline Item & C & $\mathbf{H}$ & $\mathbf{O}$ & $\mathbf{N}$ & $\mathbf{S}$ & $\mathrm{Cl}$ & Ash & Moisture & $\begin{array}{c}\text { Percentage } \\
\text { in total waste }\end{array}$ \\
\hline $\begin{array}{c}\text { Solid waste } \\
\text { (plastic, wood, and paper) }\end{array}$ & 75.2 & 7.8 & 8.1 & 0.2 & 0.1 & 3.1 & 5.1 & 0.4 & 56 \\
\hline $\begin{array}{l}\text { Liquid waste } \\
\text { (oil and paint) }\end{array}$ & 33.4 & 3.5 & 0.1 & 0.1 & 0.2 & 1.3 & 33.0 & 28.4 & 10 \\
\hline $\begin{array}{c}\text { Miscellaneous } \\
\text { (sewage sludge and food waste) }\end{array}$ & 8.5 & 1.1 & 0.1 & 0.0 & 0.2 & 0.0 & 30.0 & 60.1 & 34 \\
\hline
\end{tabular}

Note: Analyses are expressed in weight $\%$. 
temperature and a long holding time. The hot flue gases from the afterburner are cooled off in a boiler, prior to cleaning, which enable to recover the heat energy in the form of steam. Removal of pollutants from flue gas of the incineration plants, through filtration and absorption of pollutants, is generally carried out by dry, semi-dry and wet processes. Semi-dry process normally provides reasonably better performance with alkaline reagent (e.g. lime slurry) addition. In addition, when activated carbon is mixed with lime slurry, the process can efficiently capture dioxins and furans. The flue gases released from the incinerator are passed through the semi dry reactor (SDR), bag filter (BF), and induced draft fan (IDF) followed by wet scrubber (WS). The SDR is generally suitable for the removal of acidic gases such as $\mathrm{HCl}, \mathrm{HF}$, and $\mathrm{SO}_{\mathrm{x}}$ from incinerator. This system injects an aqueous adsorbent like $\mathrm{Ca}(\mathrm{OH})_{2}$ slurry, with higher sorbent concentration. As the hot flue gas is mixed with the aqueous sorbent, water is evaporated from the slurry. The water which remains on the solid adsorbent enhances the reaction with $\mathrm{SO}_{2}$. Eventually, the process forms a dry waste product which is collected by a BF. The captured dust blown off from the base falls into a hopper, which is then evacuated by an appropriate device. Subsequently, the IDF exhausts the flue gas onto the WS. In this system, the flue gas is ducted to a spray tower where adsorbent slurry is injected into the flue gas. The WS removes the acidic constituents $(\mathrm{HF}, \mathrm{HCl}$ and $\mathrm{H}_{2} \mathrm{SO}_{4}$ ) present in the flue gas. Moisture present in the slurry is partially removed which results in the saturation of the waste gas stream. The $\mathrm{SO}_{2}$ dissolves into the slurry droplets, thereby reacting with the alkaline particulates. The wastewater generated from some of the processes is disposed to the ash pit and is allowed for natural evaporation. Steam $\left(8.5 \mathrm{kgf} / \mathrm{cm}^{2}\right.$, $180^{\circ} \mathrm{C}$ ) is generated in the waste heat boiler at an average of 4,694 tonnes/mon, with a minimum of 2,388 tonnes/mon and a maximum of 6,197 tonnes/mon.

\subsection{Goal and Scope Definition}

The goal of this study is to evaluate the environmental impact contributed by each unit process during the incineration plant operation. Fig. 2 shows inputs and outputs in seven unit processes in the incineration plant: Pretreatment, incinerator, boiler, SDR, $\mathrm{BF}$, IDF, and WS.

Based on the functional unit of 1 tonne of industrial waste incineration, the input data related to raw materials, ancillary materials, utility, ash landfilling, steam recovery, and emission to air were collected and calculated (Table 2). The mass balance calculation for each process was based on the incineration plant design information and $\mathrm{CO}_{2}$ emission was calculated based on the elemental analysis of the incinerated wastes [25]. The emission of other air pollutants (such as $\mathrm{CO}, \mathrm{NO}_{\mathrm{x}}$ and $\mathrm{SO}_{\mathrm{x}}$ ) was measured from the stack for $5 \mathrm{~d}$ and its average values were used for this study. The emission of $\mathrm{CO}_{2}, \mathrm{CH}_{4}$ and $\mathrm{N}_{2} \mathrm{O}$ resulted due to the use of diesel while heating up the incinerator was calculated based on the manufacture and industry emission factors [26]. And the other emissions such as $\mathrm{NO}_{\mathrm{x}}$ and $\mathrm{SO}_{\mathrm{x}}$ were calculated based on the emission factors from Korea Energy Management Corporation (KEMCO) [27].

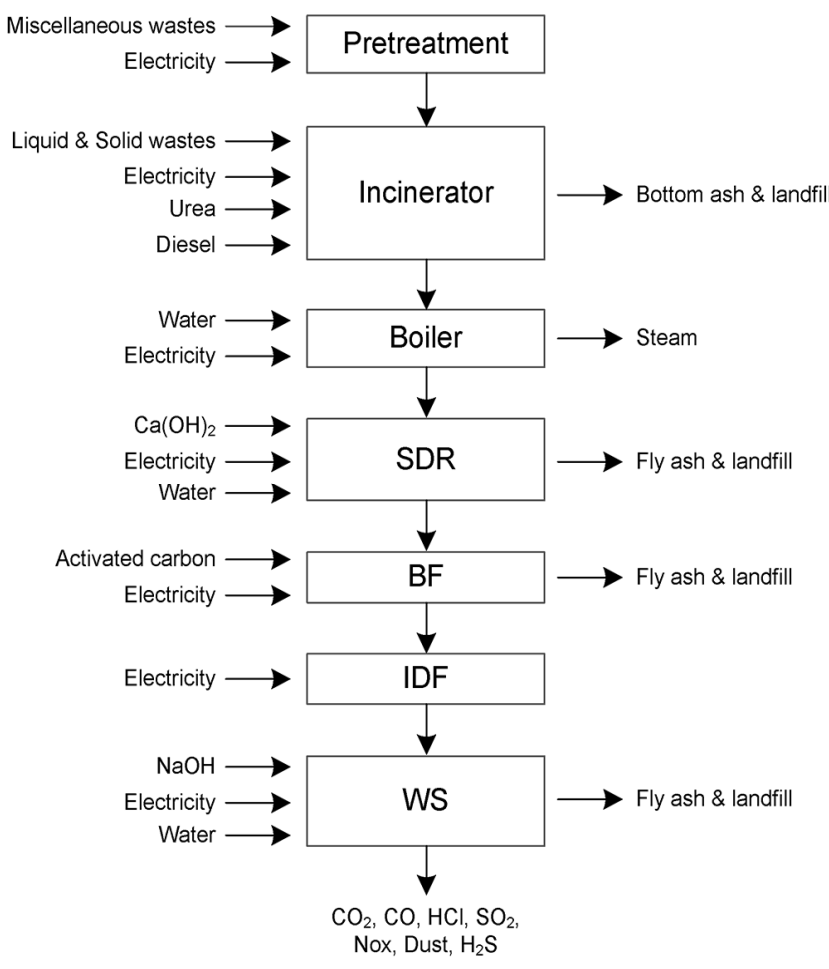

Fig. 2. Inputs and outputs for 1 ton of industrial waste incineration (SDR: Semi-Dry Reactor, BF: Bag Filter, IDF: Induced Draft Fan, WS: Wet Scrubber).

In the company to operate the subject incineration plant, there was no data about the removal of pollutants in the unit processes. This study calculated the removal of pollutants such as $\mathrm{HCl}, \mathrm{SO}_{\mathrm{x}}, \mathrm{NO}_{\mathrm{x}}, \mathrm{CO}, \mathrm{HF}, \mathrm{HCN}, \mathrm{H}_{2} \mathrm{~S}, \mathrm{NH}_{3}, \mathrm{HCHO}$, and heavy metals such as lead, copper, zinc and chromium based on their removal efficiency in waste incineration facilities [28, 29]. This study evaluated the variation of the environmental impact by the unit processes by considering that the removal of gaseous air emissions in SDR and WS process is 90\%, and that of particulate air emissions in BF and WS process is $90 \%$. Meanwhile, the impact variation for dioxin by the unit processes is not considered in this study due to lack of data on the generation and removal efficiency of dioxin in each unit process. However, the company operating the incineration plant has the data on the final emission concentration of dioxin from the stack and the dioxin emission in the stack is included in direct emission.

\subsection{Life Cycle Inventory Analysis and Impact Assessment}

Table 2 shows input and output data pertaining to raw materials, ancillary materials and utilities (water, bunker-C oil and electricity), emission to air and wastes/products. Based on this data, a life cycle inventory (LCI) of gate-to-grave material inputs and emissions were compiled using Korean LCI database (KEITI) [30]. The LCI database of Ministry of Environment (MOE) was used for industrial water, $\mathrm{NaOH}$ (caustic soda), $\mathrm{Ca}(\mathrm{OH})_{2}$, and activated carbon. Similarly for diesel, electricity, and steam, 
Table 2. Input and Output in Each Waste Incineration Process

\begin{tabular}{|c|c|c|c|c|c|c|c|c|c|c|}
\hline & & Item & Unit & Pretreatment & Incinerator & Boiler & SDR & BF & IDF & WS \\
\hline \multirow{10}{*}{ Input } & \multirow{3}{*}{$\begin{array}{c}\text { Raw } \\
\text { materials }\end{array}$} & Liquid waste & ton & 1.025 & & & & & & \\
\hline & & Drum waste & ton & & 0.101 & & & & & \\
\hline & & Solid waste & ton & & 0.557 & & & & & \\
\hline & \multirow{4}{*}{$\begin{array}{l}\text { Ancillary } \\
\text { materials }\end{array}$} & Urea & $\mathrm{kg}$ & & 2.8 & & & & & \\
\hline & & $\mathrm{Ca}(\mathrm{OH})_{2}$ & kg & & & & 37.3 & & & \multirow{3}{*}{6.1} \\
\hline & & $\mathrm{NaOH}$ & $\mathrm{kg}$ & & & & & & & \\
\hline & & Activated carbon & $\mathrm{kg}$ & & & & & 0.82 & & \\
\hline & \multirow{3}{*}{ Utility } & Water & $\mathrm{kg}$ & & & 1,650 & 149 & & & 901 \\
\hline & & Diesel & $\mathrm{kg}$ & & 0.105 & & & & & \\
\hline & & Electricity & $\mathrm{kWh}$ & 43.4 & 40.8 & 9.6 & 10.4 & 10.1 & 33 & 8.2 \\
\hline \multirow{2}{*}{ Output } & \multirow{2}{*}{$\begin{array}{l}\text { Wastes/ } \\
\text { Products }\end{array}$} & Ash & $\mathrm{kg}$ & & 140 & & 35 & 61 & & 15 \\
\hline & & Steam & MJ & & & 4,539 & & & & \\
\hline
\end{tabular}

Source: Yoosung Corp. Ltd.

the LCI database provided by Ministry of Trade, Industry and Energy (MOTIE) was used while that for urea and ash landfill, Ecoinvent LCI database [31] was used.

The resulting LCI details for each incineration unit process are summarized in Table 3. The impact categories considered in the evaluation are ADP, AP, EP, GWP, ODP, POCP, human toxicity potential (HTP), and eco-toxicity potential (ETP). The life cycle impact assessment (LCIA) methodology in this study is based on the Korean eco-indicator [32], which has been modified to suit Korea's industrial situation with Eco-indicator 95 method [33-35]. This LCIA methodology was used to assess and compare the environmental impact in each unit process of the incineration plant. Transport has a minor impact in the total emissions, when comparing with other phase [36-38]. Therefore, this study has excluded the environmental impact from the transportation phase for chemicals and ash landfilling.

\section{Results and Discussion}

\subsection{Environmental Impacts of Unit Processes in the Incineration Plant}

The change in environmental impact due to direct and indirect emission by the gradual addition of unit processes is shown in Fig. 3. The environmental impact due to direct emission was noticeably decreased, especially after the addition of SDR. In the boiler process, the impact due to direct emission was visibly decreased because there is no ash landfilling. And in the BF process, the impact due to direct emission was marginally increased because of ash landfilling. Meanwhile, the impact due to indirect emission was slightly increased. Though it appears that there is a marginal decrease in environmental impact due to direct emission after the addition of BF, IDF and WS, the reduction in this category in the real world situation cannot be ruled out. This is because BFs have the ability to efficiently capture (more than 90\%) dioxins, which usually poses significant toxicity and can have severe environmental impact. Nevertheless, accurate estimation was not possible due to lack of data/information. The higher impact due to indirect emission as observed in SDR, BF and WS was mainly contributed by the energy and raw material consumption. Therefore it is clear that underestimation of impact due to indirect emission can result in biased conclusion. Though addition of the unit processes is essential to meet the air quality control guideline, careful estimation of overall impact (both in the downstream as well as in the upstream) is highly required.

This part of the study considered waste disposal as the incinerator's sole function and explained the total environmental impact due to direct and indirect emissions associated with each process. In this part, we considered the final environmental impact produced from the stack. The environmental impact due to air emissions emitted from the stack was considered to be the impact of the incineration process. That is because of the air emissions emitted from stack is produced by the incineration process. The characterization results showed the ADP to be 0.621 $\mathrm{y}^{-1}$ of waste incineration. With regard to ADP, contributions of SDR, incinerator, and pretreatment were $49 \%, 15 \%$ and $12 \%$, respectively, and the highest contribution of SDR in this category was entirely due to indirect emission (Fig. 4(a)). This is because SDR process consumes significant amount of raw material and energy including electricity, $\mathrm{Ca}(\mathrm{OH})_{2}$, and water. Besides, the ash discharged from this process also requires energy for its disposal in the landfill site. In this process, the effect of $\mathrm{Ca}(\mathrm{OH})_{2}$ that was used to remove acidified gases was the highest (88\%). The estimated AP of $1.66 \mathrm{~kg} \mathrm{SO}$-eq. was mainly contributed by the incinerator $(68 \%)$, SDR $(11 \%)$ and pretreatment $(6 \%)$ processes. Air emission from the incinerator resulted in AP of $1.0 \mathrm{~kg}$ of $\mathrm{SO}_{2}$-eq. and disposal of ash to landfill resulted in $0.1 \mathrm{~kg} \mathrm{SO} \mathrm{S}_{2}$-eq. With a total of $2.32 \mathrm{~kg} \mathrm{PO}_{4}{ }^{3-}$-eq. of waste incineration in the EP category, the contribution of the incinerator and $\mathrm{BF}$ were $57 \%$ and $23 \%$, respectively. The GWP was 1,970 $\mathrm{kg} \mathrm{CO}$-eq. due to waste incineration, of which the contribution of $\mathrm{CO}_{2}$ was $93.4 \%$. In an earlier study on MSW incineration, 
Table 3. Summarized Results of Inventory Analysis for Each Process

\begin{tabular}{|c|c|c|c|c|c|c|c|c|c|}
\hline & Inventory parameter & Unit & Pre-treatment & Incinerator & Boiler & SDR & Bag Filter & ID Fan & Wet scrubber \\
\hline I & (r) Coal & $\mathrm{kg}$ & $7.62 \mathrm{E}+00$ & $1.15 \mathrm{E}+01$ & $1.74 \mathrm{E}+00$ & $2.57 \mathrm{E}+00$ & $3.06 \mathrm{E}+00$ & $5.80 \mathrm{E}+00$ & $2.84 \mathrm{E}+00$ \\
\hline I & (r) Natural gas & $\mathrm{kg}$ & 9.77E-01 & $9.24 \mathrm{E}-01$ & $2.28 \mathrm{E}-01$ & $1.52 \mathrm{E}+01$ & $2.27 \mathrm{E}-01$ & 7.43E-01 & $1.15 \mathrm{E}+00$ \\
\hline I & (r) Crude oil & $\mathrm{kg}$ & $9.44 \mathrm{E}-01$ & 9.95E-01 & $2.19 \mathrm{E}-01$ & $1.47 \mathrm{E}+00$ & $2.20 \mathrm{E}-01$ & 7.18E-01 & 8.44E-01 \\
\hline I & (r) Water & $\mathrm{kg}$ & $9.01 \mathrm{E}-01$ & 8.63E-01 & $1.70 \mathrm{E}+03$ & $1.54 \mathrm{E}+02$ & $2.10 \mathrm{E}-01$ & $6.85 \mathrm{E}-01$ & $9.62 \mathrm{E}+02$ \\
\hline I & (r) Limestone & $\mathrm{kg}$ & 1.97E-05 & $0.00 \mathrm{E}+00$ & $1.66 \mathrm{E}-04$ & 4.91E-04 & $0.00 \mathrm{E}+00$ & $1.50 \mathrm{E}-05$ & 5.12E-04 \\
\hline I & (r) Iron ore $(46 \%)$ & $\mathrm{kg}$ & $0.00 \mathrm{E}+00$ & $1.23 \mathrm{E}+01$ & $1.24 \mathrm{E}-05$ & $2.94 \mathrm{E}+00$ & $5.12 \mathrm{E}+00$ & $0.00 \mathrm{E}+00$ & $1.26 \mathrm{E}+00$ \\
\hline I & (r) Sodium chloride & $\mathrm{kg}$ & 6.19E-04 & 7.37E-01 & $1.03 \mathrm{E}-03$ & 1.89E-01 & 3.14E-01 & 4.70E-04 & $3.78 \mathrm{E}+00$ \\
\hline I & (r) Clay & $\mathrm{kg}$ & 7.72E-06 & 1.92E-01 & $1.71 \mathrm{E}-06$ & 4.61E-02 & 8.03E-02 & 5.87E-06 & 1.97E-02 \\
\hline I & (r) Aluminium & $\mathrm{kg}$ & $0.00 \mathrm{E}+00$ & 1.44E-01 & $0.00 \mathrm{E}+00$ & 3.23E-02 & 5.62E-02 & $0.00 \mathrm{E}+00$ & 1.38E-02 \\
\hline I & (r) Zinc - copper ore $(4.07 \%-2.59 \%)$ & $\mathrm{kg}$ & $0.00 \mathrm{E}+00$ & $4.30 \mathrm{E}-02$ & $0.00 \mathrm{E}+00$ & 9.53E-03 & 1.66E-02 & $0.00 \mathrm{E}+00$ & 4.09E-03 \\
\hline I & (r) Dolomite & $\mathrm{kg}$ & $0.00 \mathrm{E}+00$ & 2.59E-02 & 1.03E-07 & 6.19E-03 & 1.07E-02 & $0.00 \mathrm{E}+00$ & 6.13E-03 \\
\hline I & (r) Kaolinite & $\mathrm{kg}$ & $0.00 \mathrm{E}+00$ & 2.03E-03 & $5.84 \mathrm{E}-08$ & 4.98E-04 & 8.67E-04 & $0.00 \mathrm{E}+00$ & 2.14E-04 \\
\hline I & (r) Sand & $\mathrm{kg}$ & 2.92E-07 & 1.19E-03 & 2.09E-06 & 2.94E-04 & 5.12E-04 & $2.22 \mathrm{E}-07$ & 4.40E-02 \\
\hline I & (r) Sulfur & $\mathrm{kg}$ & $0.00 \mathrm{E}+00$ & 1.14E-03 & 3.47E-03 & 5.98E-04 & 4.93E-04 & $0.00 \mathrm{E}+00$ & 2.12E-03 \\
\hline I & (r) Lead & $\mathrm{kg}$ & $0.00 \mathrm{E}+00$ & 3.39E-04 & 5.04E-09 & $0.00 \mathrm{E}+00$ & $1.08 \mathrm{E}-04$ & $0.00 \mathrm{E}+00$ & $3.16 \mathrm{E}-05$ \\
\hline I & (r) Caliche & $\mathrm{kg}$ & 3.05E-04 & $2.86 \mathrm{E}-04$ & $6.97 \mathrm{E}-05$ & 7.32E-05 & 7.09E-05 & $2.32 \mathrm{E}-04$ & $1.01 \mathrm{E}-04$ \\
\hline I & (r) Wood & $\mathrm{kg}$ & $1.08 \mathrm{E}-07$ & 5.37E-04 & $2.48 \mathrm{E}-08$ & $1.82 \mathrm{E}+02$ & 2.19E-04 & $8.24 \mathrm{E}-08$ & 5.39E-05 \\
\hline $\mathrm{O}$ & (a) $\mathrm{CO}_{2}$, fossil & $\mathrm{kg}$ & $2.11 \mathrm{E}+01$ & $1.84 \mathrm{E}+03$ & $4.84 \mathrm{E}+00$ & $3.56 \mathrm{E}+01$ & $2.54 \mathrm{E}+01$ & $1.61 \mathrm{E}+01$ & $1.27 \mathrm{E}+01$ \\
\hline $\mathrm{O}$ & (a) Sulfur dioxide & $\mathrm{kg}$ & 7.07E-02 & 4.19E-01 & $1.56 \mathrm{E}-02$ & $2.55 \mathrm{E}-02$ & 3.91E-02 & $5.38 \mathrm{E}-02$ & 2.11E-02 \\
\hline $\mathrm{O}$ & (a) Nitrogen oxides & $\mathrm{kg}$ & 5.18E-02 & 8.72E-01 & 1.19E-02 & $2.28 \mathrm{E}-01$ & $5.76 \mathrm{E}-02$ & 3.94E-02 & 3.27E-02 \\
\hline $\mathrm{O}$ & (a) Hydrocarbons & $\mathrm{kg}$ & 4.37E-02 & 4.11E-02 & $1.00 \mathrm{E}-02$ & 1.35E-02 & 1.03E-02 & 3.32E-02 & $1.45 \mathrm{E}-02$ \\
\hline $\mathrm{O}$ & (a) Methane, fossil & $\mathrm{kg}$ & 1.53E-02 & 3.69E-02 & 3.51E-03 & $2.17 \mathrm{E}-02$ & 4.39E-03 & $1.17 \mathrm{E}-02$ & $6.49 \mathrm{E}-03$ \\
\hline $\mathrm{O}$ & (a) CO, fossil & $\mathrm{kg}$ & $2.10 \mathrm{E}-03$ & 3.72E-01 & $4.86 \mathrm{E}-04$ & $1.28 \mathrm{E}-02$ & $2.29 \mathrm{E}-02$ & $1.60 \mathrm{E}-03$ & $6.00 \mathrm{E}-03$ \\
\hline $\mathrm{O}$ & (a) Ammonia & $\mathrm{kg}$ & 4.86E-05 & $1.06 \mathrm{E}-02$ & $1.11 \mathrm{E}-05$ & $3.98 \mathrm{E}-04$ & $6.66 \mathrm{E}-04$ & $3.70 \mathrm{E}-05$ & 1.77E-04 \\
\hline $\mathrm{O}$ & (a) Acetaldehyde & $\mathrm{kg}$ & 6.63E-06 & 4.13E-05 & 1.52E-06 & $9.78 \mathrm{E}-06$ & 1.50E-05 & $5.04 \mathrm{E}-06$ & 5.52E-06 \\
\hline $\mathrm{O}$ & (a) Zinc & $\mathrm{kg}$ & 4.60E-06 & 3.07E-03 & $1.05 \mathrm{E}-06$ & 1.91E-06 & 1.82E-06 & $3.50 \mathrm{E}-06$ & 1.71E-06 \\
\hline $\mathrm{O}$ & (a) Hydrogen chloride & $\mathrm{kg}$ & 2.06E-07 & $6.76 \mathrm{E}-02$ & $1.25 \mathrm{E}-07$ & $1.22 \mathrm{E}-04$ & $1.84 \mathrm{E}-04$ & $1.57 \mathrm{E}-07$ & 4.68E-05 \\
\hline $\mathrm{O}$ & (a) Hydrogen fluoride & $\mathrm{kg}$ & $2.01 \mathrm{E}-07$ & $1.73 \mathrm{E}-02$ & $1.57 \mathrm{E}-06$ & $2.30 \mathrm{E}-05$ & $9.24 \mathrm{E}-06$ & $1.53 \mathrm{E}-07$ & $3.10 \mathrm{E}-05$ \\
\hline $\mathrm{O}$ & (a) Phenol & $\mathrm{kg}$ & 7.46E-08 & $6.93 \mathrm{E}-07$ & $1.71 \mathrm{E}-08$ & 1.13E-07 & $1.74 \mathrm{E}-07$ & $5.68 \mathrm{E}-08$ & 6.37E-08 \\
\hline $\mathrm{O}$ & (a) Chlorine & $\mathrm{kg}$ & 9.03E-09 & $2.46 \mathrm{E}-06$ & 2.16E-09 & $1.08 \mathrm{E}-07$ & $1.85 \mathrm{E}-07$ & $6.86 \mathrm{E}-09$ & 2.89E-07 \\
\hline $\mathrm{O}$ & (a) Nickel & $\mathrm{kg}$ & 3.67E-09 & 2.04E-05 & $8.40 \mathrm{E}-10$ & $1.22 \mathrm{E}-06$ & 1.99E-06 & 2.79E-09 & 5.58E-07 \\
\hline $\mathrm{O}$ & (a) Benzene & $\mathrm{kg}$ & 2.64E-09 & 7.90E-05 & $6.05 \mathrm{E}-10$ & 9.82E-06 & $1.54 \mathrm{E}-05$ & 2.01E-09 & 3.85E-06 \\
\hline $\mathrm{O}$ & (a) Lead & $\mathrm{kg}$ & $3.66 \mathrm{E}-10$ & $1.41 \mathrm{E}-03$ & 8.37E-11 & $1.76 \mathrm{E}-07$ & 2.30E-07 & $2.78 \mathrm{E}-10$ & $6.35 \mathrm{E}-08$ \\
\hline $\mathrm{O}$ & (a) Cadmium & $\mathrm{kg}$ & $1.51 \mathrm{E}-10$ & 1.13E-06 & $3.46 \mathrm{E}-11$ & $1.52 \mathrm{E}-08$ & $2.09 \mathrm{E}-08$ & $1.15 \mathrm{E}-10$ & 8.59E-09 \\
\hline $\mathrm{O}$ & (a) Manganese & $\mathrm{kg}$ & $5.64 \mathrm{E}-11$ & $1.12 \mathrm{E}-06$ & $1.29 \mathrm{E}-11$ & $1.56 \mathrm{E}-07$ & $2.73 \mathrm{E}-07$ & $4.29 \mathrm{E}-11$ & $6.71 \mathrm{E}-08$ \\
\hline $\mathrm{O}$ & (a) Halon 1301 & $\mathrm{~kg}$ & $4.95 \mathrm{E}-11$ & 2.02E-07 & $1.09 \mathrm{E}-11$ & 7.31E-08 & $1.11 \mathrm{E}-07$ & $3.76 \mathrm{E}-11$ & 1.93E-08 \\
\hline \multirow[t]{2}{*}{$\mathrm{O}$} & (a) Mercury & $\mathrm{kg}$ & $2.50 \mathrm{E}-11$ & 4.04E-07 & $5.73 \mathrm{E}-12$ & $2.54 \mathrm{E}-08$ & 3.03E-08 & 1.90E-11 & 8.09E-09 \\
\hline & (w) Dissolved solids & $\mathrm{kg}$ & $1.37 \mathrm{E}-01$ & $1.29 \mathrm{E}-01$ & 3.13E-02 & $4.24 \mathrm{E}-02$ & $3.22 \mathrm{E}-02$ & $1.04 \mathrm{E}-01$ & 4.54E-02 \\
\hline
\end{tabular}

I - input; O - output; (r) - resources; (a) - air emissions; (w) - water emissions

the major cause of climate change was demonstrated as $\mathrm{CO}_{2}$ emission [39]. The POCP was $0.049 \mathrm{~kg} \mathrm{C}_{2} \mathrm{H}_{4}$-eq. of waste incineration in which the incinerator contributed to $74 \%$ of the total impact.
The HTP and ETP were $131.2 \mathrm{~kg}$ 1,4 DCB-eq. and 1,490 kg 1,4 DCB-eq. of waste incineration, respectively, in which the contributions of incinerator and $\mathrm{BF}$ were $59 \%, 56 \%$ and $22 \%, 24 \%$, 
Table 4. Weighting Results

\begin{tabular}{|c|c|c|c|c|c|c|c|c|c|}
\hline $\begin{array}{l}\text { Category } \\
\text { Process }\end{array}$ & ADP & AP & EP & GWP & ODP & РОСР & HTP & ETP & Total \\
\hline Pretreatment & 4.82.E-05 & 1.21.E-04 & 4.56.E-05 & 8.00.E-04 & 3.11.E-08 & 2.26.E-05 & 9.82.E-05 & 4.04.E-06 & 1.14.E-03 \\
\hline Incinerator & 6.02.E-05 & 1.29.E-03 & 8.86.E-03 & 6.90.E-02 & 1.36.E-05 & 2.32.E-04 & 1.22.E-01 & 4.56.E-01 & 6.57.E-01 \\
\hline Boiler & 1.11.E-05 & 2.72.E-05 & 1.04.E-05 & 1.83.E-04 & 7.44.E-09 & 5.01.E-06 & 2.27.E-05 & 9.42.E-07 & 2.61.E-04 \\
\hline SDR & 1.94.E-04 & 2.11.E-04 & 2.22.E-03 & 1.36.E-03 & 1.97.E-06 & 1.12.E-05 & 2.71.E-02 & 1.12.E-01 & 1.43.E-01 \\
\hline Bag filter & 1.50.E-05 & 9.17.E-05 & 3.56.E-03 & 9.71.E-04 & 3.02.E-06 & 1.67.E-05 & 4.52.E-02 & 1.95.E-01 & 2.45.E-01 \\
\hline ID fan & 3.66.E-05 & 9.24.E-05 & 3.46.E-05 & 6.09.E-04 & 2.37.E-08 & 1.72.E-05 & 7.46.E-05 & 3.07.E-06 & 8.67.E-04 \\
\hline Wet scrubber & 3.44.E-05 & 5.04.E-05 & 8.93.E-04 & 4.89.E-04 & 1.39.E-06 & 7.93.E-06 & 1.21.E-02 & 4.81.E-02 & 6.18.E-02 \\
\hline Total & 4.00.E-04 & 1.88.E-03 & 1.56.E-02 & 7.34.E-02 & 2.01.E-05 & 3.13.E-04 & 2.06.E-01 & 8.11.E-01 & 1.11.E+00 \\
\hline
\end{tabular}

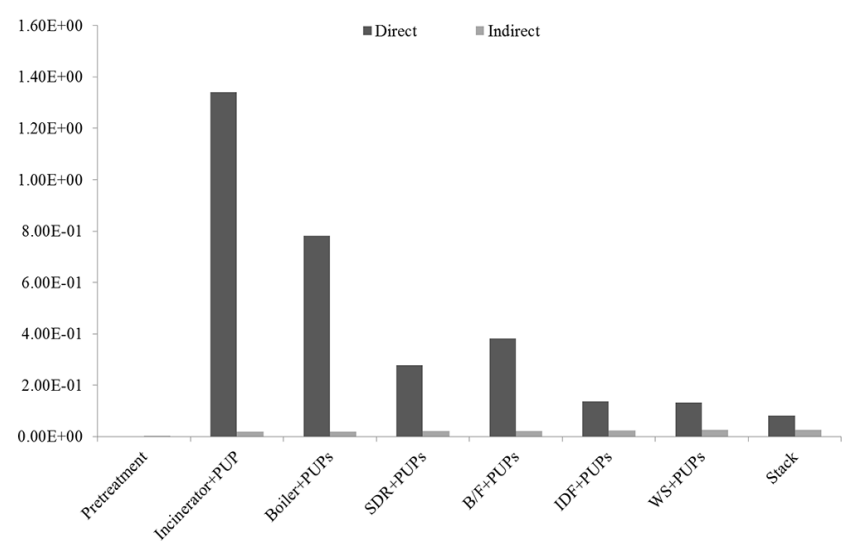

Fig. 3. Change in environmental impact due to direct and indirect emissions by addition of unit processes (PUP: Previous unit process).

respectively. Landfilling of ash contributed significantly to the HTP (92\%) and ETP (99\%) categories. Fruergaard et al. [40] have demonstrated similar result due to landfilling of air pollution control residues (fly ash or bottom ash) on HTP and ETP categories. The contribution of incinerators to HTP and ETP categories has also been described elsewhere [41]. According to data on the final emission concentration of dioxin, a nanogram level of dioxin is emitted at the final stage. By considering this dioxin concentration, the HTP and ETP of waste incineration were increased by $4.95 \mathrm{~kg} 1,4$ DCB-eq. (126.21 kg 1,4 DCB-eq. $\rightarrow 131.16 \mathrm{~kg} 1,4$ DCB-eq.) and $0.76 \mathrm{~kg} 1,4$ DCB-eq. $(1,488.87 \mathrm{~kg}$ 1,4 DCB-eq. $\rightarrow \quad 1,489.63 \mathrm{~kg}$ 1,4 DCB-eq.), respectively. The dioxin's characterization factors to HTP and ETP are high, but the emitted dioxin quantity is too low in terms of the nanogram level. The impact by dioxin is therefore insignificant. In this study, the impact due to dioxin is only considered to be minor.

The environmental impact due to direct emission was predominant as $97.7 \%$, but the indirect emission was only minor at $2.3 \%$. The indirect emission was $2.4 \%$ of the direct emission (Fig. 4(b)). The significant contribution of direct emission is attributed to the landfilling of ash, while the indirect emission is attributed to the use of electricity and urea. Other than ADP and ODP catego- ries, the environmental impact of incinerator was mainly due to the direct emission (Fig. 4(a)). The ODP was 9.64E-06 kg CFC 11-eq. of waste incineration, of which the incinerator contributed to as high as $68 \%$, mainly due to the indirect emission as a result of urea consumption and the direct emission as a result of ash landfilling.

There are different units for environmental impact categories in the characterization results. But through the normalization and weighting steps, the environmental impact can be compared with each category. The normalization and weighting factors used in this study were adopted from Korean eco-indicator [32, 33]. Table 4 shows the weighted environmental impact of each unit process in the incineration plant. Among the processes, incinerator had the most environmental impact (59\%) and $\mathrm{BF}$ had $22 \%$ of total environmental impact. Eco-toxicity stands out as the impact category with highest damage score (73\%), followed by human toxicity (19\%).

Comparing non-toxicity impact categories (ADP, AP, EP, ODP, GWP, and POCP) and toxicity related impact categories (ETP and HTP), toxicity related impact is dominant at $91.7 \%$ while non-toxicity impact is insignificant at $8.3 \%$ [Fig. 5]. This result indicated that the toxicity should be considered in the evaluation of the environmental impact for incineration. Meanwhile, according to our previous study [24], the incinerator had the highest environmental impact at $87 \%$ and SDR had the second highest impact at $5 \%$ among other processes. GWP accounted the highest impact score (more than $85 \%$ ), followed by eutrophication (6\%) among the various categories of environmental impact. Quantitative direct and indirect impacts were $89 \%$ and $11 \%$, respectively. Considering toxicity categories, the impact of the incinerator was decreased, and the impacts of toxicity categories were the first (ETP) and second (HTP) highest. The impact due to direct emission was also increased from $89 \%$ to $98 \%$.

\subsection{Avoided Impact Due to Steam Recovery}

Energy recovery, in the past, has led to the introduction of a typical LCA concept. The environmental impact or damage through the energy gained (in terms of thermal or electric energy) due to waste incineration avoid the consumption of fossil fuels and reduce the emission of pollutants for an equivalent amount of energy (avoided environmental impact) [42]. 

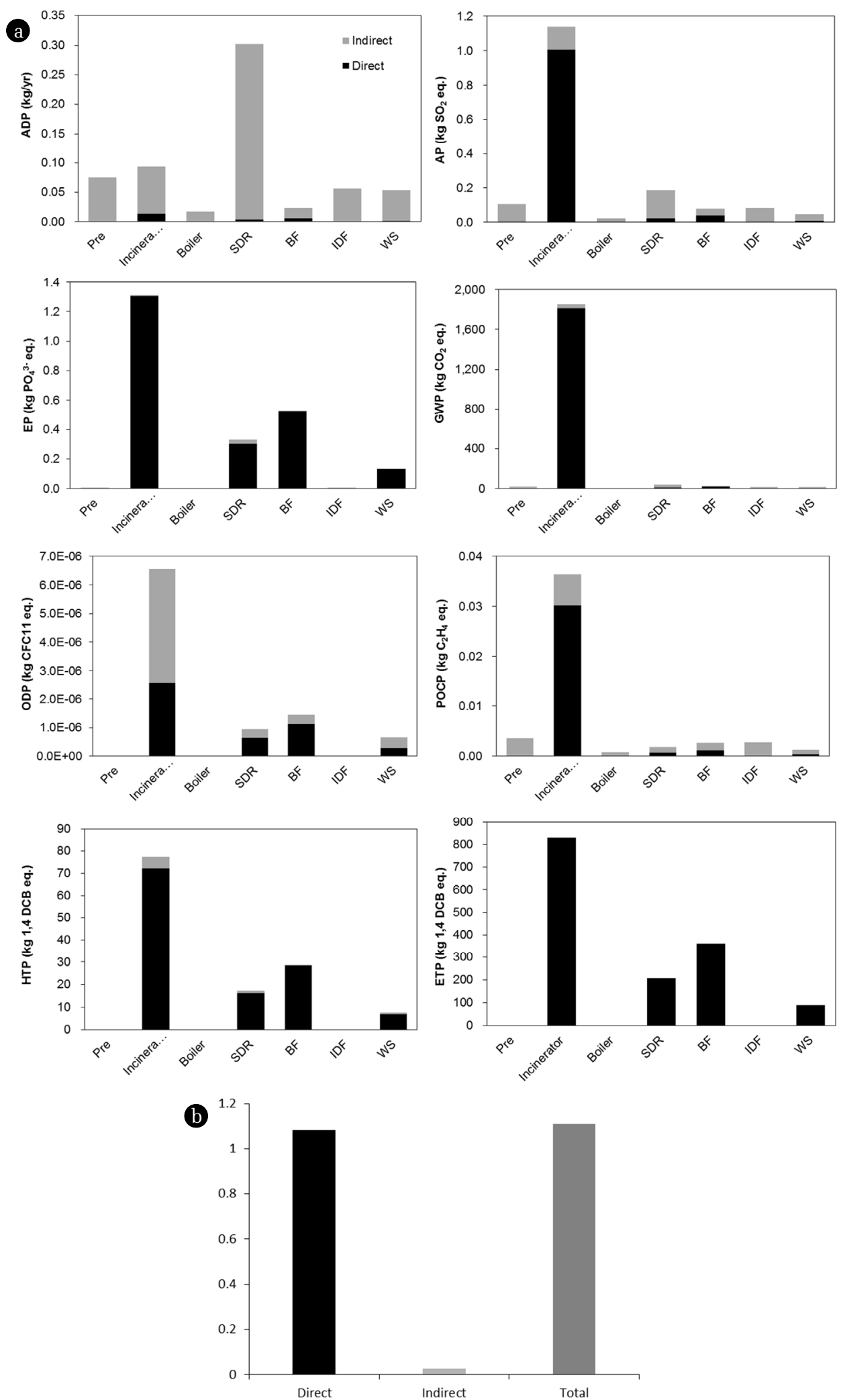

Fig. 4. Valuation of total environmental impacts in each process with respect to various impact categories (Pre: Pretreatment, SDR: Semi-Dry Reactor, BF: Bag Filter, IDF: Induced Draft Fan, WS: Wet Scrubber). 


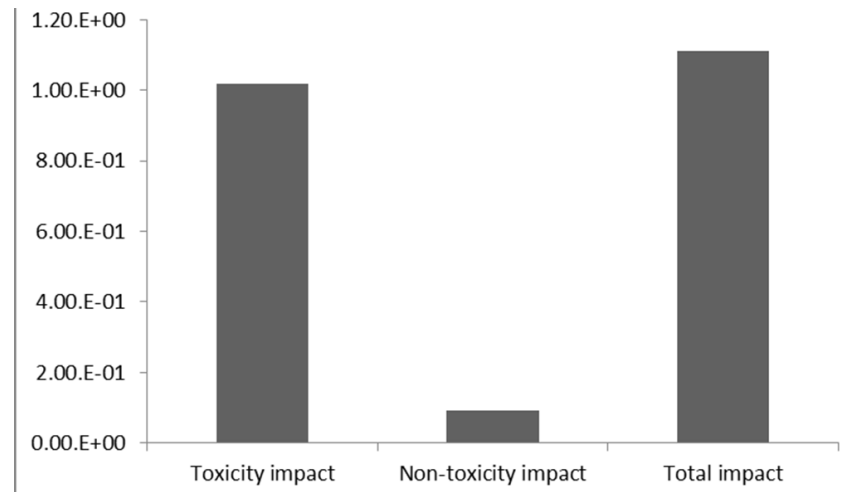

Fig. 5. Valuation of non-toxicity impact and toxicity impact.

In this section, steam recovery from the waste heat of an industrial waste incinerator was evaluated, i.e. the incinerator was studied for waste disposal as well as energy recovery functions. Presently, there exists a steam network between the incineration plant under discussion and a nearby paper mill. The steam produced in the boiler using waste heat obtained from the incinerator can reduce emissions that would have otherwise been produced by other energy systems using fossil energy vectors. Recently, energy recovery including steam has been considered as a necessary condition for new generation incineration plants for which these two functions should be considered together [43, 44]. The results shown in Fig. 6 have both positive and negative value: positive value means a positive environmental impact and, as a consequence there is damage at the environmental level. On the contrary, negative value means a negative environmental impact, which is equivalent to an avoided burden. From the life cycle view point, the incineration plant with steam production is able to assure greater avoided impacts for the categories ADP, AP, ODP, POCP, and HTP. Referring to ADP category, environmental impact due to incineration was $0.62 \mathrm{~kg} / \mathrm{y}$ and the avoided impact was $2.61 \mathrm{~kg} / \mathrm{y}$ (Fig. 6(a)). Therefore, the net environmental impact was $-1.98 \mathrm{~kg} / \mathrm{y}$. In the case of GWP category, the environmental impact of incineration was $1,970 \mathrm{~kg} \mathrm{CO}_{2}$-eq. and the avoided impact due to steam production was $484 \mathrm{~kg} \mathrm{CO}$-eq. with a net impact of 1,486 $\mathrm{kg} \mathrm{CO}_{2}$-eq. (about 25\% reduction of total GWP). Similarly, in terms of EP and ETP categories, the environmental impact of incineration was $2.32 \mathrm{~kg} \mathrm{PO}_{4}{ }^{3-}$-eq. and 1,490 $\mathrm{kg} \mathrm{1,4}$ DCB-eq. and the avoided impact was $0.16 \mathrm{~kg} \mathrm{PO}_{4}{ }^{3-}$-eq. and 512 $\mathrm{kg} 1,4$ DCB-eq., respectively with a net impact of $2.16 \mathrm{~kg} \mathrm{PO}_{4}{ }^{3-}$-eq. and $977 \mathrm{~kg}$ 1,4 DCB-eq. Even though there was no avoided burden in the GWP, EP and ETP categories, the overall impact due to steam recovery resulted in negative environmental impact (Fig. 6(b)). In the 'no energy recovery' scenario (incineration only), a net environmental impact is observed, as the incineration system is not credited with any avoided emissions. But, as soon as there was energy (steam) recovery, five of the eight impact categories showed an overall saving.

It must be kept in mind that the type of fuel substituted (Bunker-C oil) can have as much influence as that of the energy recovery from the incinerator and also that of substituted energy source (e.g., electricity, steam, etc.). Incineration of MSW, with energy recovery as the auxiliary function, allows for production of electricity by exploiting the heat of flue gases. This has shown to compensate the environmental damages by avoiding the use of energy obtained from fossil fuel exploitation [45]. It has also been reported that greenhouse gas emission due to MSW incineration was reduced by $14.6 \%$ as a consequence of avoided electricity production from conventional power production [46].

\subsection{Implication of the Result}

LCA of the incineration plant showed that steam recovery from waste heat has resulted in the negative environmental impact. However, consideration of the economic aspects of putting the results into practice is beyond the scope of this analysis. One way of using the produced steam in the incineration plant was its supply through a steam network. The efficiency of steam and electricity co-generation is $62 \%$ [47], which indicates that the efficiency of steam production alone from waste heat could be higher (> 70\%). This value is quite higher than the efficiency of electricity production (35\%) from waste heat [47]. Therefore, from the view point of industrial requirement, steam production was encouraged from the waste heat of the incinerators present in the industrial complexes. The incineration plant is supplying 10 steam tonne/h to the paper mill. The paper mill is economically benefitted in terms of its relaxation from the taxes levied on it for consuming fossil fuel (bunker-C oil), which was conventionally used for steam production. On the other hand, waste incineration plant, as the supplier of steam; derive revenue from receiving the waste from other companies as well as selling steam to the paper mill. For instance, the incineration plant and the paper mill share an annual profit of 2.32 million US $\$ / y$ while reducing 19,058 tonne $\mathrm{CO}_{2} / \mathrm{y}$ and 135 tonne/y of other air pollutants including $\mathrm{SO}_{\mathrm{x}}, \mathrm{NO}_{\mathrm{x}}$, $\mathrm{CO}$, etc. [48]. Comparing the situation when the plants operated in isolation, the utilization of waste heat from incineration plant introduces both economic and environmental benefits and, maximizing energy recovery by waste incineration was desirable. In a similar view point, the methodology applied in this study can be adopted to other types of environmental infrastructures such as wastewater treatment facilities or landfills wherein the reuse of wastewater effluents or recovered biogas can play the same role of avoidance as that observed in this study in the form of steam recovery from waste heat.

Stringent environmental regulations imposed in the recent days put tremendous pressure on various environmental infrastructures to drastically reduce the pollutant emissions. Eventually, it results in the addition of more unit processes to the existing infrastructures. However, inclusion of additional unit processes for better environmental quality warrants a comprehensive life-cycle understanding of the performance of various processes in such facilities. This shall not only help in assessing the impacts of the various individual unit processes but also help to get the feedback on improving the operational efficiency of these processes minimizing the overall environmental impact. As evident from this study, the location of incinerators should not only consider impacts due to direct emission. It should also consider impact due to indirect emission as well as avoided 

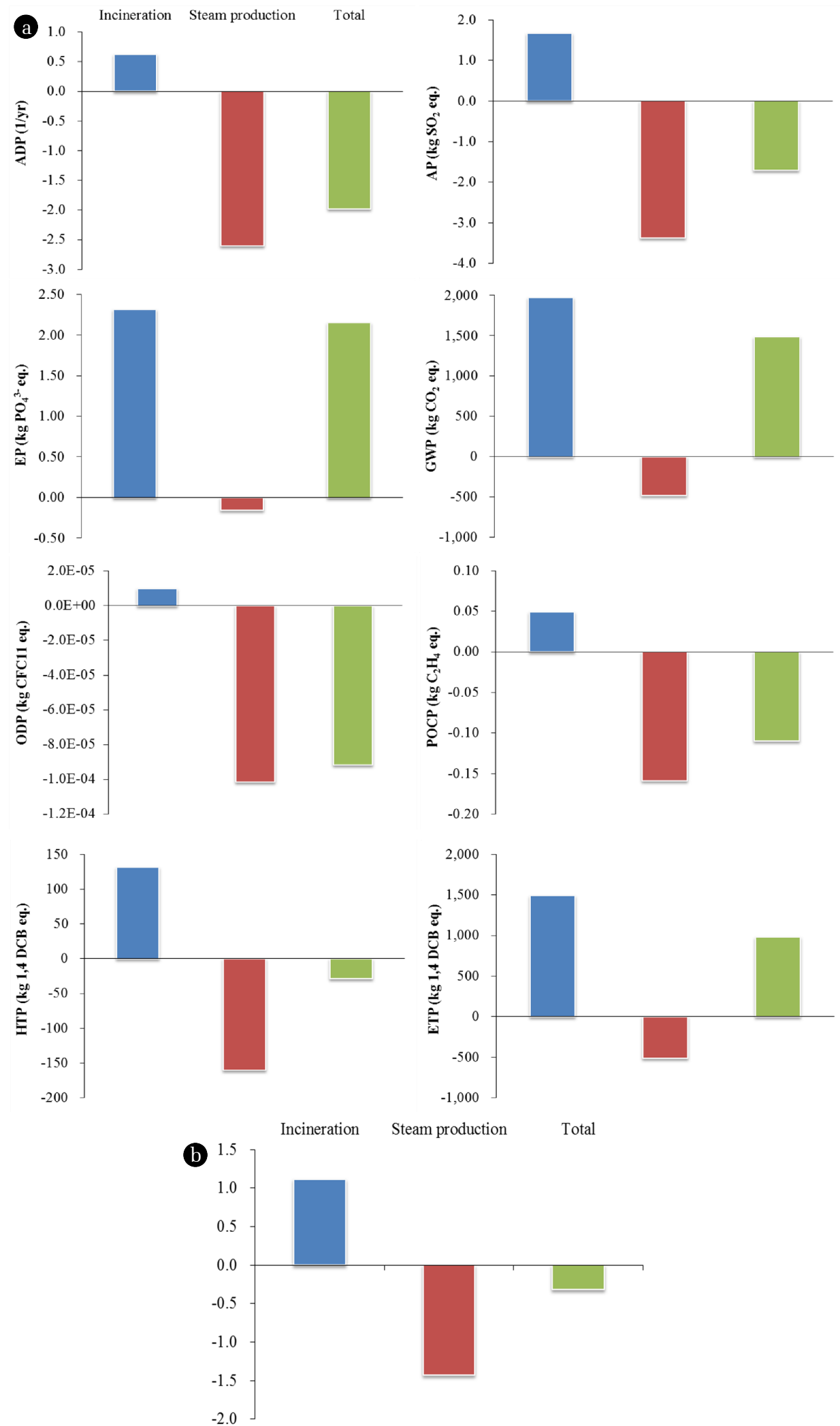

Fig. 6. Change in environmental impact due to the steam recovery. 
impacts, if any, to aid in decision making processes. The regulations pertaining to the location of waste incinerators within industrial complexes should take into account the synergistic effect of benefits resulting out of sharing or exchange of wastes or energies.

\section{Conclusions}

The methodology adopted in this study can be applied to different kinds of environmental infrastructures in order to evaluate their performance. In this study, LCA is focused on the operational phase of the incineration plant, primarily due to the higher environmental impact incurred in this stage as compared to the construction and demolition phases. As a whole, results on the variation of the environmental impact by the unit processes showed that the direct impact were decreased by $79.3 \%, 71.6 \%$, and $90.1 \%$ by the SDR, BF and WS processes, respectively. In the BF process, the impact due to direct emission was increased by ash landfilling. In consideration to the final environmental impact produced from the stack, the toxicity impact categories like ETP and HTP were predominant at $91.7 \%$ of the total impact. In the toxicity impact categories, the environmental impact in the ETP category was found to be most significant. Separate estimation of impacts pertaining to direct and indirect emissions showed that of the impact due to direct emissions is $97.7 \%$ of the total impact. This result demonstrated that the environmental impacts due to the direct emission should be highly considered before the establishment of incinerators in a city or a region and should be supported by the policy decisions. Meanwhile, the impact due to direct emission could reduce to control air pollutants through air emission control processes. And because the use of electricity and urea is the main contribution for indirect emission, the impact due to indirect emission could be reduced by minimizing electricity consumption through the utilization of renewable energy and the heat generated by the incineration process and by substituting urea to an alternate material in order to remove $\mathrm{NO}_{\mathrm{x}}$. The significant environmental impact reduction owing to steam recovery indicated that the industrial complexes, with the requirement for very high quantity of energy, may consider using steam recovered from waste incineration plants. The study, limited to the assessment of the incineration process performances, can be extended for performing a most detailed analysis considering the impact due to dioxin emission and the release of many other heavy metals.

\section{Acknowledgements}

This research was supported by a grant (code 08 RTI B-03) from Regional Technology Innovation Program funded by Ministry of Land Transport and Maritime Affairs of Korean government. SKB thankfully acknowledges the Brain Korea 21 Post-doctoral fellowship from the Ministry of Education, Science and Technology through the Environmental Engineering Program at the University of Ulsan.

\section{References}

1. Standard ISO. Environmental management - Life cycle assessment-Principles and framework. ISO; 2006.

2. Chester MV, Horvath A. Environmental assessment of passenger transportation should include infrastructure and supply chains. Environ. Res. Lett. 2009;4:1-8.

3. Horvath A, Hendrickson C. Steel versus steel-reinforced concrete bridges: Environmental assessment. J. Infrastruct. Syst. 1998;4:111-117.

4. Ochoa L, Hendrickson C, Matthews HS. Economic input-output life-cycle assessment of U.S. residential buildings. J. Infrastruct. Syst. 2002;8:132-138.

5. Keoleian GA, Kendall A, Chandler RF, Helfand GE, Lepech MD. Life cycle model for evaluating the sustainability of concrete infrastructure systems. In: 9th International Conference on Structural Safety and Reliability Proceedings; 20-23 June 2005; Rome, Italy: Millpress; 2005. p. 19-23.

6. Bilec MM, Ries RJ, Matthews HS. Life-cycle assessment modeling of construction processes for buildings. J. Infrastruct. Syst. 2010;16:199-205.

7. Sharrard AL, Matthews HS, Ries RJ. Estimating construction project environmental effects using an input-output-based hybrid life-cycle assessment model. J. Infrastruct. Syst. 2008;14: 327-336.

8. Kato H, Shibahara N, Osaba M, Hayashi Y. A life cycle assessment for evaluating environmental impacts of inter-regional high speed mass transit projects. J. East Asia Soc. Transport Stud. 2005;6:3211-3224.

9. Treloar GJ, Love PED, Crawford RH. Hybrid life-cycle inventory for road construction and use. J. Constr. Eng. M. ASCE. 2004;130:43-49.

10. Miliutenko S. Literature review: Assessment of energy use and greenhouse gas emissions generated by transport infrastructure. KTH (Environmental Strategies Research), Stockholm; 2010.

11. Tillman AM, Svingby M, Lundoström H. Life cycle assessment of municipal wastewater systems. Int. J. Life Cycle Assess. 1998;3:145-157.

12. Lundin M, Bergtsson M, Molander S. Life cycle assessment of wastewater systems: Influence of system boundaries and scale on calculated environmental loads. Environ. Sci. Technol. 2000;34:180-186.

13. Lim SR, Park DH, Park JM. Environmental and economic feasibility study of a total wastewater treatment network system. J. Environ. Manage. 2008;88:564-575.

14. Renou S, Thomas JS, Aoustin E, Pons MN. Influence of impact assessment methods in wastewater treatment LCA. J. Clean. Prod. 2008;16:1098-1105.

15. Finnveden G. Methodological aspects of life cycle assessment of integrated solid waste management systems. Resour. Conserv. Recy. 1999;26:173-187.

16. Diaz R, Warith M. Life cycle assessment of municipal solid wastes: Development of the WASTED model. Waste Manage. 2006;26:886-901.

17. Su J, Chiueh P, Hung M, Ma H. Analyzing policy impact potential for municipal solid waste management decision-mak- 
ing: A case study of Taiwan. Resour. Conserv. Recy. 2007;51:418-434.

18. Winkler J, Bilitewski B. Comparative evaluation of life cycle assessment models for solid waste management. Waste Manage. 2007;27:1021-1031.

19. Manfredi S, Christensen TH. Environmental assessment of solid waste landfilling technologies by means of LCAmodelling. Waste Manage. 2009;29:32-43.

20. Graedel TE, Allenby BR. Industrial ecology. 2nd ed. New Jersy: Prentice Hall; 2003.

21. Jay K, Stieglitz L. Identification and quantification of volatile organic components in emissions of waste incineration plants. Chemosphere 1995;30:1249-1260.

22. Mocarelli P, Gerthoux PM, Ferrari E, et al. Paternal concentrations of dioxin and sex ratio of offspring. The Lancet 2000;355:1858-1863.

23. AENews. Negative impacts of incineration-based waste-to-energy technology [Internet]. AENews; c2016 [cited 16 November 2016]. Available from: http://www.alternative-energy-news.info/negative-impacts-waste-to-energy/.

24. Kim HW, Kim KH, Park HS. Environmental impact evaluation and improvement measure of incineration plant by life cycle assessment. J. Korea Org. Resour. Recy. Assoc. 2013;21:86-98 (in Korean).

25. Song KK, Choi BC. Combustion engineering. Seoul; Cheong Moon Gak publisher; 2005 (in Korean).

26. Gómez DR, et al. Stationary combustion. In: Eggleston S, Buendia L, Miwa K, Ngara T, Tanabe K, eds. IGES. Hayama; 2006. p. 16-17.

27. KEMCO (Korea Energy Management Corporation). Conversion factor of air pollutant emissions from energy source [Internet]. KEMCO; c2015 [cited 11 October 2015]. Available from: h t t p :// w w w. ke m co.or.kr/up_load/we a ther/pds/PDS00098_2002525_001. htm.

28. Park GH, Kim BH, Lee ES. Pilot plant operation for incineration flue gas treatment by SDA (Spray Dryer Absorption). J. Korea Soc. Waste Manage. 2001;18:161-171 (in Korean).

29. Ryu HY, Kim MC, Jung JH, Lee GW, Chung JD. A study on $\mathrm{NO}_{\mathrm{x}}$ removal efficiency using SNCR process in the industrial waste incineration plant. Korea J. Environ. Health 2005;31: 332-339 (in Korean).

30. KEITI (Korea Environmental Industry and Technology Institute). Korea LCI database information network [Internet]. KEITI; c2015 [cited 15 December 2015]. Available from: http://www.edp.or.kr/en/lci/lci_intro.asp.

31. Swiss centre for life cycle inventories. Ecoinvent databases Data V2.01 [Internet]. Ecoinvent; c2015 [cited 20 November 2015]. Available from: http://db.ecoinvent.org/ ecoquery.

32. Lee KM. A weighting method for the Korean eco-indicator. Int. J. Life Cycle Ass. 1999;4:161-165.

33. Heo YC, Suh SW, Ha SS, Lee KM. Determination of normalization value for Korean eco-indicator. J. Korea Soc. Life Cycle
Assess. 2000;4:24-35 (in Korean).

34. Uh SG, Kim JW, Han KB, Kim CW. Life cycle impacts of flexible-fiber deep-bed filter compared to sand-filter including coagulation and sedimentation in water treatment plant. Environ. Eng. Res. 2008;13:1-9.

35. PRe Consultants. LCA Learning Library [Internet]. PRe Consultants; c2015 [cited 10 November 2015]. Available from: https://www.pre-sustainability.com/lca-learning-library.

36. Amorim C, Sgps S. Evaluation of the environmental impacts of cork stoppers versus aluminum and plastic closuresAnalysis of the life cycle of cork, aluminum and plastic wine closures. Price water house coopers/Ecobilan; 2008 October.

37. Tähkämö L, Martinsons C, Ravel P, Grannec F, Zissis G. Solid state lighting annex: Life cycle assessment of solid state lighting. International Energy Agency 4E Solid State Lighting Annex Task 1; 2014.

38. Vince F, Aoustin E, Bréant P, Marechal F. LCA tool for the environmental evaluation of potable water production. Desalination 2008;220:37-56.

39. Scipioni A, Mazzi A, Niero M, Boatto T. LCA to choose among alternative design solutions: The case study of a new Italian incineration line. Waste Manage. 2009;29:2463-2474.

40. Fruergaard T, Hyks J, Astrup T. Life-cycle assessment of selected management options for air pollution control residues from waste incineration. Sci. Total Environ. 2010;408:4672-4680.

41. Riber, C, Bhander GS, Hauschild M, Christensen TH. Environmental assessment of waste incineration in a life-cycle-perspective (EASEWASTE). Waste Manage. Res. 2008;26: 96-103.

42. Morselli L, Robertis CD, Luzi J, Passarini F, Vassura I. Environmental impacts of waste incineration in a regional system (Emilia Romagna, Italy) evaluated from a life cycle perspective. J. Hazard. Mater. 2008;159:505-511.

43. Fruergaard T, Astrup T. Optimal utilization of waste-to-energy in an LCA perspective. Waste Manage. 2011;31:572-582.

44. Damgaard A, Riber C, Fruergaard T, Hulgaard T, Christensen TH. Life-cycle-assessment of the historical development of air pollution control and energy recovery in waste incineration. Waste Manage. 2010;30:1244-1250.

45. Scipioni A, Mastrobuono M, Mazzi A, Manzardo A. Voluntary GHG management using a life cycle approach - A case study. J. Clean Prod. 2010;18:299-306.

46. Liamsanguan C, Gheewala SH. LCA: A decision support tool for environmental assessment of MSW management systems. J. Environ. Manage. 2008;87:132-138.

47. Cha JH, et al. Energy total solutions, Seoul: Korea Energy Information Center; 2003 (in Korean).

48. Park HS. Practical experiences from eco-industrial park project in Ulsan, Republic of Korea. Presented in UNIDO Green Industry Forum@Shanghai World Exposition. Shanghai, China; 24 May 2010. 